DOI: https://doi.org/10.24144/2409-6857.2018.1(51).416-424

УДК 657.433.9

Карпенко I.B.

\title{
МЕТОДИКА ОБЛІКУ ТРАНСФЕРТНОГО ЦІНОУТВОРЕННЯ НА ПІДПРИСМСТВАХ ТОРГІВЛІ
}

\begin{abstract}
У статті викладені результати дослідження основних етапів процесу обліку трансфертного ціноутворення на підприємстві торгівлі, в тому числі виокремлення та вирішення проблемних питань щзодо обліку контрольованих операщій. За результатами дослідження здійснено узагальнення рахунків та запропонована системи аналітичних рахунків для обліку розрахунків між пов'язаними особами. Розглянуті форми первинних документів, в яких відображається інформація про здійснення операцій $з$ трансфертними цінами та запропонований реєстр для ідентифікації таких операцій. Досліджено відображення інформації про трансфертне цүіноутворення в управлінській, фінансовій та податковій звітності.
\end{abstract}

Ключові слова: трансфертна ціна, контрольована операція, договір про попереднє ціноутворення, розрахунки між пов'язаними особами, звіт про контрольовані операції.

Постановка проблеми. У 2016 році частка ВВП у торгівлі в Україні становила 24,9\%. Державна фіскальна служба України затвердила реєстр великих платників податків на 2018 рік, який налічує 2594 підприємств, що на 82 підприємства більше ніж у реєстрі на 2017 рік. Торгівля входить до п'яти основних галузей платників, великі платники податків в торгівлі складають 10,6\% [1]. Великі підприємства зазвичай здійснюють діяльність в формі певного об'єднання (групи підприємств), масштаби їх діяльності впливають на формування відокремлених структурних підрозділів, підприємств спільної діяльності, тому їх необхідно розглядати як потенційних суб'єктів трансфертного ціноутворення.

Проблема обліку операцій 3 трансфертними цінами є однією з найменш досліджених ділянок обліку в сучасних умовах. Аналіз літературних джерел показав, що на методику обліку трансфертного ціноутворення не було звернено достатньо уваги, автори розглядають методи формування трансфертної ціни, управлінський облік за центрами відповідальності та облік внутрішніх розрахунків, не виокремлюючи розрахунки за операціями 3 використанням трансфертних цін. Необхідні теоретичні та практичні дослідження методики бухгалтерського обліку трансфертного ціноутворення, формування облікової політики щодо операцій 3 пов'язаними особами та звітності по контрольованих операціях.

(C) Карпенко Інна Вікторівна, аспірант кафедри обліку та оподаткування, Київський національний торговельно-економічний університет, м. Київ, тел.: 0975998480, email: ik.rielty@gmail.com
Аналіз останніх досліджень і публікацій. Дослідженням теоретичних та методичних основ обліку трансфертного ціноутворення, внутрішніх розрахунків, процесу формування трансфертної ціни та консолідації фінансової звітності займались наступні вітчизняні вчені економісти: Алексєєва А. [2], Жукова О.В. [3], Мельник М.I. [4], Рогова Н.В. [5], Засадний Б. [6], Литвиненко Н.О. [7], Голов С.Ф., Костюченко В.М. [8], Семчук І.В., Озеран А.В., Уманців Г.В., Гойло Н.В. [9], Мішин М.О. [10], Кругляк В.В. Праці названих вчених стали основою подальшого докладнішого дослідження питань податкового контролю операцій із застосуванням трансфертного ціноутворення, управлінського обліку за центрами відповідальності та методів встановлення трансфертної ціни на підприємствах. При цьому окремі питання щодо методики обліку трансфертного ціноутворення 3 урахуванням особливостей діяльності підприємств торгівлі залишається малодослідженим. Це свідчить про актуальність теми, а відтак зумовило вибір напряму дослідження в науковому i практичному аспектах.

Формулювання цілей статті. Метою статті $\epsilon$ визначення та дослідження основних етапів процесу обліку трансфертного ціноутворення на підприємстві торгівлі, а також виокремлення та вирішення проблемних питань щодо обліку контрольованих операцій.

Опис основного матеріалу дослідження. Організація бухгалтерського обліку на підприємствах - це система методів, способів та заходів, які забезпечують оптимальне функціонування такого обліку та подальший його розвиток. Така організація полягає в цілеспрямованому впорядкуванні й удос- 
коналенні механізму, структури та процесів бухгалтерського обліку [11]. Ключове місце в організації бухгалтерського обліку трансфертного ціноутворення займає вибір методики ведення обліку операцій 3 трансфертними цінами. Відповідно до тлумачення сутності поняття «методика» (великий тлумачний словник) методика обліку трансфертного ціноутворення - це сукупність та послідовність застосування певних способів та методів бухгалтерського обліку, що забезпечують практичне виконання конкретних завдань обліку трансфертних цін.

В бухгалтерському обліку операції 3 трансфертними цінами розглядалися вченими переважно в контексті управлінського обліку витрат за центрами відповідальності. Стрімке зростання кількості операцій між пов'язаними особами та зміна умов податкового законодавства щодо звітування про здійснення операцій 3 трансфертними цінами обумовлює необхідність забезпечення повного та оперативного облікового відображення інформації про такі господарські операції. У зв'язку 3 цим виникає необхідність вдосконалення системи бухгалтерського обліку операцій 3 трансфертними цінами та розгляд трансфертного ціноутворення в системі фінансового обліку. Необхідно встановити на підприємстві процедуру збору, систематизації та подання інформації по трансфертному ціноутворенню, шляхом відображення операцій 3 трансфертними цінами на рахунках та облікових регістрах, формування звітності зовнішнім та внутрішнім користувачам відповідно до вимог чинного законодавства. Облік трансфертного ціноутворення передбачає дотримання вимог затверджених нормативно-правових документів та вказівок контролюючих органів. Це пов'язано 3 тим, що застосування трансфертних цін має суттєвий вплив на розрахунок й своєчасну сплату підприємством податку на прибуток. Також за допомогою обліку вирішується потреба у внутрішній інформації для процесу встановлення трансфертної ціни.

В такому разі об'єктом фінансового обліку трансфертного ціноутворення $€$ формування трансфертної ціни в контрольованих операціях, розрахунки за контрольованими операціями, дохід від здійснення контрольованих операцій та їх оподаткування.

Встановлений алгоритм виявлення контрольованих угод на підприємстві для обліку повинен бути гнучким для оперативного реагування на зміни в законодавстві. Необхідний постійний моніторинг чинного податкового законодавства, адже умови за яких операція відноситься до контрольованої можуть змінюватися. Алгоритм виявлення контрольованих угод за національним законодавством наведено в табл. 1.

Таблиця 1

Алгоритм виявлення контрольованих угод за національним законодавством*

\begin{tabular}{|c|c|c|}
\hline Етап & $\begin{array}{c}\text { Критерії відбору } \\
\text { контрольованих операцій }\end{array}$ & Умова визнання господарської операції контрольованою \\
\hline $\mathrm{I}$ & $\begin{array}{l}\text { Річний дохід підприємства, } \\
\text { визначений за правилами } \\
\text { бухгалтерського обліку }\end{array}$ & $\begin{array}{l}\text { перевищує } 150 \text { мільйонів гривень (за вирахуванням непрямих } \\
\text { податків) за рік }\end{array}$ \\
\hline II & 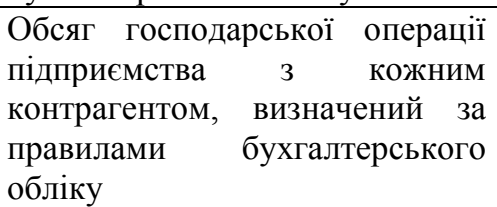 & $\begin{array}{l}\text { перевищує } 10 \text { мільйонів гривень (за вирахуванням непрямих } \\
\text { податків) за рік }\end{array}$ \\
\hline III & $\begin{array}{l}\text { Вид контрагента } \\
\text { діяльність }\end{array}$ & $\begin{array}{l}\text { господарські операції, що здійснюються } 3 \text { пов’язаними } \\
\text { особами- нерезидентами; } \\
\text { зовнішньоекономічні господарські операції з продажу та/або } \\
\text { придбання товарів та/або послуг через комісіонерів- } \\
\text { нерезидентів; } \\
\text { господарські операції, що здійснюються } 3 \text { нерезидентами, які } \\
\text { зареєстровані, або є резидентами у державах (на територіях), } \\
\text { включених до переліку, затвердженого Кабінетом Міністрів } \\
\text { України; } \\
\text { господарські операції, що здійснюються } 3 \text { нерезидентами, які } \\
\text { не сплачують податок на прибуток (корпоративний податок); } \\
\text { господарські операції, що здійснюються між нерезидентом та } \\
\text { його постійним представництвом в Україні. }\end{array}$ \\
\hline
\end{tabular}

* Розроблено автором на основі [12] 
Облік контрольованих операцій є важливою частиною обліку операцій 3 трансфертними цінами на підприємствах торгівлі.

Для об'єктивного та достовірного відображення процесу трансфертного ціноутворення в системі бухгалтерському обліку ключовим є формування облікових даних щодо операцій між пов'язаними особами та цін, що встановлюються в таких операціях. Порядок формування облікової інформації про трансфертні ціни в торговельних операціях зображений на рис. 1.

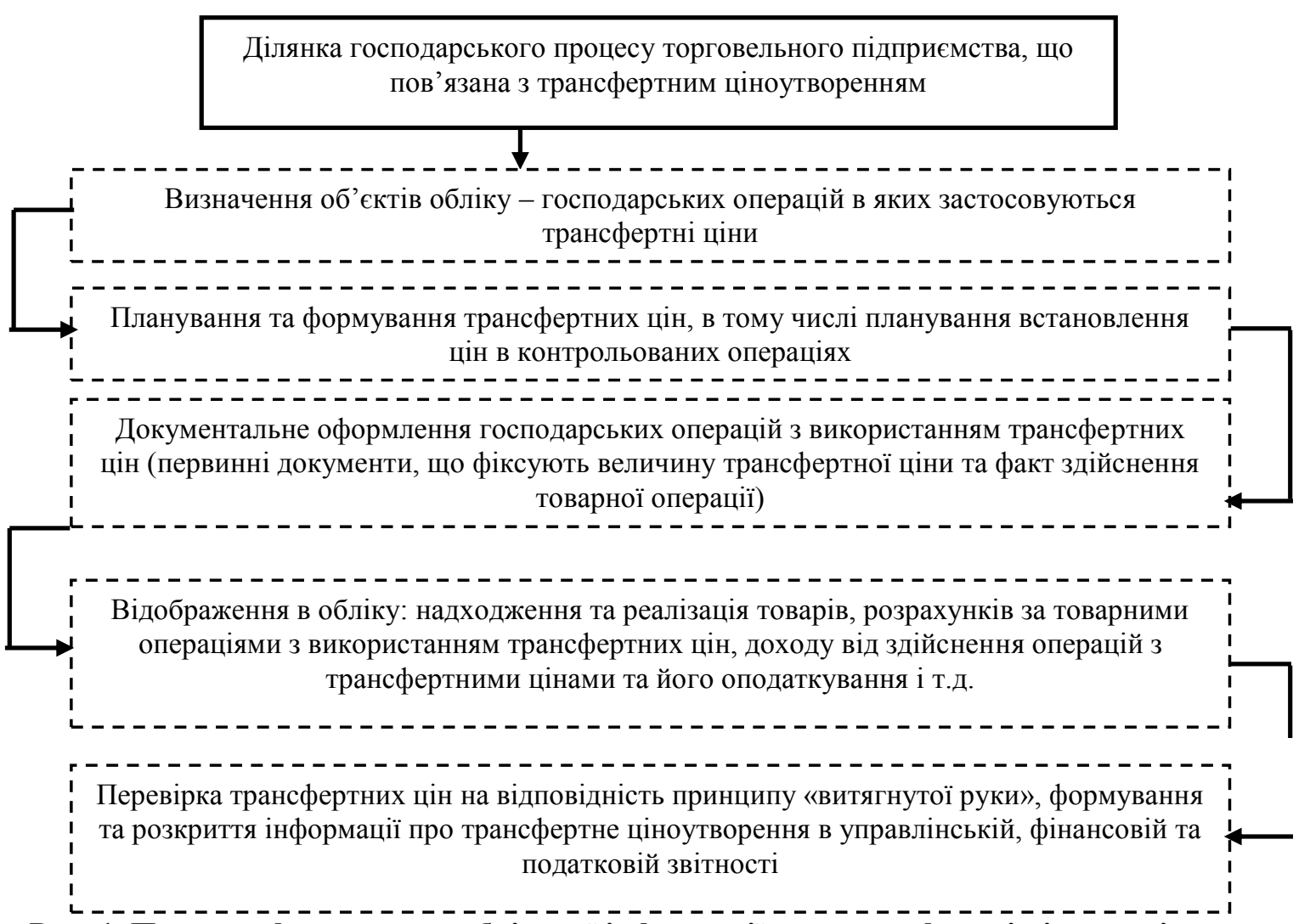

Рис. 1. Порядок формування облікової інформації про трансфертні ціни на підприємствах

*Розроблено автором торгівлі*

При цьому застосування відповідного методу трансфертного ціноутворення може відбуватися як на етапі планування та формування трансфертної ціни, так і під час перевірки трансфертних цін на відповідність принципу «витягнутої руки» та складання звітності щодо трансфертного ціноутворенню.

Встановлення трансфертної ціни в контрольованих операціях згідно принципу «витягнутої руки» передбачає використання одного із методів:

- метод порівнянної неконтрольованої ціни (Comparable Uncontrolled Price - CUP);

- метод ціни перепродажу (Resale Price Method - RPM);

- метод «витрати плюс» (Cost Plus Method CPM);

- метод чистого прибутку (Transactional Net Margin Method - TNMM);

- метод розподілення прибутку від операцій (Profit Split Method - PSM) [12].
Обрані підприємством методи та механізм їх використання слід закріпити в Положенні про облікову політику.

На етапі формування трансфертної ціни можливе укладання договору 3 контролюючими органами про попереднє ціноутворення, який характерний лише для трансфертного ціноутворення.

Договір про попереднє ціноутворення (ДПЦ) - це угода, яка визначає на етапі, що передує контрольованим операціям, відповідний набір критеріїв (наприклад, метод, параметри порівнянності і відповідні коригування, критичні припущення щодо майбутніх подій) для визначення трансфертного ціноутворення за вказаними операціями протягом встановленого періоду. Договір ДПЦ передбачає ведення переговорів між підприємством, одним або декількома асоційованими підприємствами та однією чи кількома податковими службами. ДПЦ зазвичай охоплює кілька операцій, кілька типів операцій на постійній основі, або всі 
міжнародні операції платника податків за конкретний період часу, повинен мати положення (або, можливо, посилання на деякий діапазон), що забезпечує можливість перегляду або скасування договору в майбутньому, якщо економічна діяльність підприємств істотно змінюється. Такі договори актуальні саме для торговельної продукції, в торговельних операціях спостерігається більша точність прогнозів результатів здійснення таких операцій [13]. Згідно ЗУ «Про бухгалтерський облік та фінансову звітність в Україні» первинний документ - документ, який містить відомості про господарську операцію, він може бути складений у паперовій або в електронній формі. Первинні документи, складені в електронній формі, застосовуються у бухгалтерському обліку за умови дотримання вимог законодавства про електронні документи та електронний документообіг [14].

Для оформлення товарних операцій 3 трансфертними цінами використовуються первинні документи наведені в табл. 2.

Таблиця 2

Первинні документи з обліку товарних операцій з трансфертними цінами*

\begin{tabular}{|l|l|}
\hline \multicolumn{1}{|c|}{ Назва первинного документа } & \multicolumn{1}{c|}{ Призначення } \\
\hline Договір поставки (купівлі-продажу) & $\begin{array}{l}\text { взаємовідносини постачальника і покупця оформляються } \\
\text { відповідними договорами поставки, в яких зазначаються всі умови } \\
\text { здійснення операції }\end{array}$ \\
\hline Договір зберігання товарів & $\begin{array}{l}\text { оформляється для зберігання товару, коли одна сторона (зберігач) } \\
\text { зобов'язується зберігати річ, яка передана їй другою стороною }\end{array}$ \\
\hline Акт приймання-передачі товару & документ, який фіксує факт завершення товарної операції та їі обсяг \\
\hline Прибуткова (видаткова) накладна & оформляється надходження чи відвантаження товарів \\
\hline Інвойс & $\begin{array}{l}\text { оформлений належним чином рахунок-фактура (інвойс) може бути } \\
\text { підставою для відображення в бухгалтерському обліку операції } 3 \\
\text { постачання товарів без складання акта приймання-передачі тільки у } \\
\text { разі його оплати, що підтверджується відповідними документами }\end{array}$ \\
\hline $\begin{array}{l}\text { Митна декларація } \\
\text { заповнюється для декларування товарів, що переміщуються через } \\
\text { митний кордон України }\end{array}$ \\
\hline $\begin{array}{l}\text { Подорожній лист (ф. № 1 та №2), } \\
\text { Товарно-транспортна накладна } \\
\text { (ф. №1 -ТН) }\end{array}$ & документальне оформлення операцій по перевезенню товарів \\
\hline Податкова накладна & формується з метою оподаткування ПдВ товарних операцій \\
*Розроблено автором & \multicolumn{2}{|c|}{} \\
\hline
\end{tabular}

Розглянуті форми первинних документів, в яких відображається інформація про здійснення операцій 3 трансфертними цінами, не відрізняються від загальноприйнятих форм цих документів. Тому для ідентифікації операцій трансфертного ціноутворення пропонується введення реєстру операцій, в яких використовуються трансфертні ціни.
Розроблений реєстр повинен доповнюватися інформацією про фактично здійснені операції в момент реєстрації факту здійснення такої операції, який відображений в відповідному первинному документі.

Реєстр має довільну форму для кожного підприємства, приклад такого реєстру наведено в табл. 3.

Ресстр операцій з трансфертними цінами на підприсмстві*

\begin{tabular}{|l|l|l|l|l|l|l|l|}
\hline $\begin{array}{l}\text { Повне } \\
\text { найме- } \\
\text { нування } \\
\text { особи } \\
\text { (контра- } \\
\text { гент) }\end{array}$ & $\begin{array}{l}\text { Місце- } \\
\text { знаходже- } \\
\text { особи }\end{array}$ & $\begin{array}{l}\text { Тип } \\
\text { пов'я- } \\
\text { заності } \\
\text { осіб }\end{array}$ & $\begin{array}{l}\text { Тип } \\
\text { здійсне- } \\
\text { ної } \\
\text { операції }\end{array}$ & $\begin{array}{l}\text { Дата } \\
\text { здійснення } \\
\text { операції }\end{array}$ & $\begin{array}{l}\text { Підстава } \\
\text { віднесення } \\
\text { операції } \\
\text { контрольо- } \\
\text { ваної } \\
\text { (за наявності) }\end{array}$ & $\begin{array}{l}\text { Контракт } \\
\text { (договір) } \\
\text { дата } \\
\text { номер }\end{array}$ & $\begin{array}{l}\text { Сума } \\
\text { операції } \\
\text { (в грн } \\
\text { еквівале- } \\
\text { нті на дату } \\
\text { 3дійсне- } \\
\text { ння } \\
\text { операції) }\end{array}$ \\
\hline 1
\end{tabular}

*Розроблено автором 
Дані первинних документів підлягають групуванню та відображенню на рахунках бухгалтерського обліку. Первинна облікова інформація, оброблена за різними ознаками, у вигляді облікових регістрів, аналітичних таблиць та звітності містить загальну інформацію про здійснені торговельним підприємство господарські операції без виокремлення обліково-аналітичної інформації щодо операцій, здійснених з використанням трансфертних цін.

Завдяки дослідженню переліку операцій, що відносяться до обліку трансфертного ціноутворення та аналізу діючого Плану рахунків, було визначено, що розрахунки між пов'язаними особами по операціях 3 трансфертними цінами відображаються відповідно на рахунках дебіторської та кредиторської заборгованості за відповідними субрахунками, наведені в таблиці 4.

Інформація, систематизована в таблиці, вказує на те, що розрахунки між пов'язаними особами відображаються на різних бухгалтерських рахунках. Окремо інформація про такі операції не відокремлюється, а сальдо цих рахунків містить загальну інформацію про розрахунки між пов'язаними та непов'язаними особами.

Таблиця 4

Перелік рахунків для відображення в обліку розрахунків за операціями з трансфертними цінами*

\begin{tabular}{|c|c|c|c|c|}
\hline \multicolumn{3}{|c|}{ Рахунок } & \multirow[t]{2}{*}{ Субрахунок } & \multirow[t]{2}{*}{ Типи операцій із застосуванням трансфертної ціни } \\
\hline код & Назва рахунку & & & \\
\hline \multirow[t]{3}{*}{36} & \multirow{3}{*}{\multicolumn{2}{|c|}{$\begin{array}{lr}\text { Розрахунки } & 3 \\
\text { покупцями } & \text { та } \\
\text { замовниками } & \end{array}$}} & $\begin{array}{l}361 \text { «Розрахунки } \\
\text { вітчизняними } \\
\text { покупцями» }\end{array}$ & \multirow{3}{*}{$\begin{array}{l}\text { Для обліку розрахунків } \text { по господарських } \\
\text { операціях } 3 \text { відвантаження продукції, товарів, } \\
\text { виконані роботи й послуги } 3 \text { покупцями та } \\
\text { замовниками та в яких застосовуються трансфертні } \\
\text { ціни. }\end{array}$} \\
\hline & & & $\begin{array}{l}362 \text { «Розрахунки } \\
\text { іноземними } \\
\text { покупцями» }\end{array}$ & \\
\hline & & & $\begin{array}{l}363 \text { «Розрахунки } \\
\text { учасниками ПФГ» }\end{array}$ & \\
\hline \multirow[t]{2}{*}{37} & \multirow{2}{*}{\multicolumn{2}{|c|}{$\begin{array}{l}\text { Розрахунки } \\
\text { різними } \\
\text { дебіторами }\end{array}$}} & $\begin{array}{l}373 \text { «Розрахунки за } \\
\text { нарахованими } \\
\text { доходами» }\end{array}$ & $\begin{array}{l}\text { Отримання від пов'язаних осіб дивідендів, } \\
\text { відсотків, роялті тощо. }\end{array}$ \\
\hline & & & $\begin{array}{l}377 \text { «Розрахунки } 3 \\
\text { іншими дебіторами» }\end{array}$ & $\begin{array}{l}\text { Для обліку розрахунків за іншими операціями зі } \\
\text { застосування трансфертних цін. }\end{array}$ \\
\hline \multirow[t]{3}{*}{63} & \multirow{3}{*}{\multicolumn{2}{|c|}{$\begin{array}{l}\text { Розрахунки } \\
\text { постача- } \\
\text { льниками } \\
\text { підрядниками }\end{array}$}} & $\begin{array}{l}631 \text { «Розрахунки } 3 \\
\text { вітчизняними } \\
\text { постачальниками» }\end{array}$ & \multirow[t]{3}{*}{$\begin{array}{l}\text { Для обліку розрахунків } 3 \text { постачальниками за } \\
\text { операції } 3 \text { постачання товарів, робіт, послуг зі } \\
\text { застосуванням трансфертних цін }\end{array}$} \\
\hline & & & $\begin{array}{l}632 \text { «Розрахунки } \\
\text { іноземними } \\
\text { постачальниками» }\end{array}$ & \\
\hline & & & $\begin{array}{l}633 \text { «Розрахунки } \\
\text { учасниками ПФГ» }\end{array}$ & \\
\hline \multirow[t]{5}{*}{68} & \multirow{5}{*}{\multicolumn{2}{|c|}{$\begin{array}{l}\text { Розрахунки } \\
\text { іншими } \\
\text { операціями }\end{array}$}} & $\begin{array}{l}681 \text { «Розрахунки за } \\
\text { авансами } \\
\text { одержаними» }\end{array}$ & $\begin{array}{l}\text { Для обліку одержаних авансів від покупців за } \\
\text { поставки товарів (робіт, послуг) } 3 \text { використанням } \\
\text { трансфертних цін }\end{array}$ \\
\hline & & & $\begin{array}{l}682 \quad \text { «Внутрішні } \\
\text { розрахунки» }\end{array}$ & 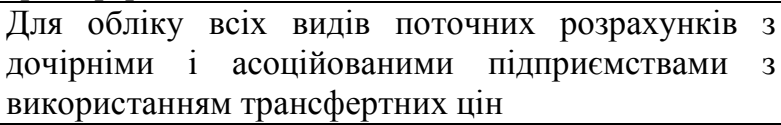 \\
\hline & & & $\begin{array}{l}\text { 683«Внутрішньо- } \\
\text { господарські } \\
\text { розрахунки» }\end{array}$ & $\begin{array}{l}\text { Для обліку внутрішньогосподарських розрахунків } 3 \\
\text { виробничими одиницями i господарствами, } \\
\text { виділеними на окремий баланс } 3 \text { використанням } \\
\text { трансфертних цін }\end{array}$ \\
\hline & & & $\begin{array}{l}684 \text { «Розрахунки } \\
\text { нарахованими } \\
\text { відсотками» }\end{array}$ & $\begin{array}{l}\text { Для обліку за нарахованими } \\
\text { операціях з пов’язатками }\end{array}$ \\
\hline & & & $\begin{array}{l}685 \text { «Розрахунки } \\
\text { іншими } \\
\text { кредиторами» }\end{array}$ & $\begin{array}{l}\text { Для обліку господарських операцій, які не } \\
\text { передбачені для обліку на інших субрахунках } \\
\text { рахунку } 68 \text { та здійснюються між пов'язаними } \\
\text { особами зі застосування трансфертних цін. }\end{array}$ \\
\hline
\end{tabular}

*Розроблено автором на основі [15] 
Такий обліковий підхід не дає можливості оперативного відображення достовірної інформації про обсяги операцій між пов'язаними особами, виокремлення операцій, які можна ідентифікувати як контрольовані, та не дає змоги оцінити залишки внутрішніх заборгованостей перед пов'язаними особами, що як результат ускладнює управління такими операціями.

Литвиненко Н.О. пропонує бухгалтерський облік усіх операцій у межах груп взаємопов'язаних підприємств, крім розрахунків 3 учасниками та розрахунків за нарахованими доходами, обліковувати на субрахунках, призначених для внутрішньогосподарських (субрахунок 683) та внутрішньогрупових (субрахунок 682) розрахунків [7, с.280].

Виникає необхідність збирання інформація про контрольовані операції на субрахунках, призначених для обліку внутрішніх розрахунків, при цьому необхідна диференціація інформації про такі операції (за контрагентами, типами господарської операції і т.д.) для достовірного відображення всіх бізнес-процесів з пов'язаними особами. Перш за все це необхідно для усунення будь-яких можливих неоднозначних тлумачень економічної сутності фінансово-господарського діяльності підприємства, пов'язаної 3 ціноутворенням. Введення окремих субрахунків для обліку розрахунків по контрольованих операціях дає можливість простежити факт здійснення контрольованих операцій та формування інформації, необхідної для звітування по таких операціях.

Для того, щоб систематизувати інформацію про операції із пов'язаними особами, а також сформувати загальну інформацію про такі операції для аналізу їх на можливість віднесення до контрольованих, пропонуємо розмежувати їх для обліку через систему аналітичних рахунків, запропоновану на рис. 2.

На схематичному зображенні структури аналітичного рахунку, призначеного для обліку операцій $з$ пов'язаними особами, перший рівень ïx деталізації (номер аналітичного рахунку першого порядку) передбачає розподіл суб'єктів господарювання за рівнем відносин на пов'язаних та непов'язаних осіб.

Другий рівень аналітичного обліку покликаний забезпечити розмежування між пов'язаними особами на резидентів та нерезидентів, що має значний вплив на визнання операції контрольованою. Використання цього рівня аналітичного обліку актуально для синтетичних рахунків першого порядку, які не мають такої деталізації (наприклад, цей рівень не застосовується для рахунку 36 «Розрахунки 3 покупцями та замовниками»). Якщо підприємством здійснюються внутрішньогосподарські розрахунки другий рівень аналітичного обліку може застосовуватися для ідентифікації організаційно-правової форми відокремленого структурного підрозділу (представництво, філія тощо).

Третій рівень аналітичності не обов'язковий для використання на підприємстві та застосовується в тому випадку якщо підприємство здійснює планування здійснення контрольованої операції та закріплює їх перелік в наказі про облікову політику чи положення про трансфертне ціноутворення на підприємстві.

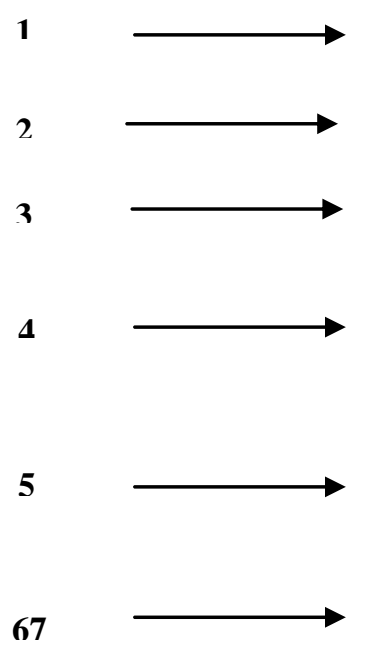

1
Клас балансового рахунку для обліку розрахунків

Синтетичний рахунок першого порядку

Рахунок другого порядку (субрахунок)

Номер аналітичного рахунку першого порядку (для розподілу суб'єктів господарювання за рівнем відносин на пов'язаних та непов'язаних осіб)

Номер аналітичного рахунку другого порядку (для розмежування пов'язаних осіб на резидентів та нерезидентів, актуально для синтетичних рахунків першого порядку, які не мають такої деталізації )

Номер аналітичного рахунку третього порядку (для деталізацію за видами операцій між пов'язаними особами)

\section{Рис. 2. Структура аналітичного рахунку, призначеного для обліку розрахунків за операціями 3 трансфертними цінами*}

*Розроблено автором 
Цей рівень передбачає деталізацію за видами операцій між пов'язаними особами на контрольовані та неконтрольовані. На четвертому рівні можливе розмежування кожного із видів операцій за переліком (номенклатурою) господарських операцій кожного виду, які здійснюють у групі підприємств.

Аналогічний підхід доцільно застосовувати для побудови аналітичних рахунків 3 обліку доходів, які рекомендовано розмежовувати на ті, що призначені для визначення сум доходів у межах групи пов'язаних підприємств та доходів від реалізації зовнішнім покупцям.

Сформовані дані узагальнюються у звітності за відповідний період 3 урахуванням того, хто $є$ користувачем цієї звітності, а саме для зовнішніх користувачів (фінансова, статистична та податкова звітність) та для внутрішніх користувачів (управлінська звітність).

В фінансовій звітності відображають суми заборгованості за розрахунками 3 пов'язаними особами у формі №1 «Баланс» (Звіт про фінансовий стан) в додаткових рядках Балансу. Це рядок 1145 «Дебіторська заборгованість за розрахунками із внутрішніх розрахунків», в який заносяться дані по сальдо Дт 682, 683 та 36, 377 (у частині пов'язаних сторін). А також рядок 1645 «Поточна кредиторська заборгованість із внутрішніх розрахунків», в якому формуються дані сальдо Кт 682, 683 та 63 (у частині зобов'язань перед пов'язаними особами), він призначений для відображення заборгованості підприємства пов'язаним сторонам і кредиторської заборгованості з внутрішніх розрахунків, зокрема між учасниками групи тощо [9, с.153]. Додаткові рядки Балансу пропонується використовувати підприємствам на власний розсуд та обгрунтовувати таку необхідність в Положенні про облікову політику підприємства.

Інформація щодо доходу від здійснення господарських операцій зі застосуванням трансфертних цін не міститься в окремих статтях форми №2 «Звіт про фінансові результати». Тому для формування даних про масштаби здійснення таких операцій за відповідний період та звітування про контрольовані операції необхідне складання окремої управлінської звітності. Форми такої звітності та інформація у звітах, яка необхідна для внутрішніх користувачів, потребують подальшого наукового дослідження.
Податкова звітність 3 трансфертного ціноутворення подається підприємством до контролюючого органу, в якому платник перебуває на обліку. Отже підприємства, які здійснювали контрольовані операції, зобов'язані до 1 жовтня наступного року після звітного подати Звіт про контрольовані операції до своєї податкової інспекції [16].

Якщо виникли розбіжності в визначенні трансфертної ціни відповідно до методу встановлення відповідності умов контрольованої операції принципу «витягнутої руки», підприємство проводить самостійне коригування податкових зобов'язань по податку на прибуток та заповнює Додаток ТЦ до Податкової декларації 3 податку на прибуток платника податку. При цьому має бути відповідність між показниками додатка ТЦ та окремими додатками до Звіту про контрольовані операції [12].

Висновки i перспективи подальших досліджень. В результаті написання статті здійснено дослідження основних етапів обліку трансфертного ціноутворення на підприємстві торгівлі. Вдосконалені процедури обліку операцій з трансфертними цінами, в тому числі виокремлені умови обліку контрольованих операцій.

За результатами дослідження здійснено узагальнення рахунків, на яких можуть обліковуватися господарські операції між пов'язаними підприємствами. Запропонована система аналітичних рахунків для обліку розрахунків між пов'язаними особами та доходу від здійснення операцій з трансфертними цінами. Розглянуті форми первинних документів, в яких відображається інформація про здійснення операцій 3 трансфертними цінами та пропонується введення реєстру для ідентифікації таких операцій. Досліджено завершальний етап обліку трансфертного ціноутворення, що полягає в формуванні, розкритті інформації про трансфертне ціноутворення в управлінській, фінансовій та податковій звітності.

Перспективним напрямком подальшого дослідження є узагальнення облікової інформації в частині формування доходу від здійснення операцій з трансфертними цінами, в тому числі доходів від проведення контрольованих операцій, оподаткування такого доходу податком на прибуток та дослідження значення такої інформації для прийняття управлінських рішень щодо трансфертного ціноутворення.

\section{ПЕРЕЛІК ВИКОРИСТАНИХ ДЖЕРЕЛ}

1. Офіційний сайт Державної фіскальної служби України [Електронний ресурс]. - Режим доступу: http://sfs.gov.ua 
2. Алексєєва А. Трансфертне ціноутворення як механізм податкового контролю / А. Алексєєва, Т. Ігнатенко // Вісник Київського національного торговельно-економічного університету. - 2014. - № 3. - С. 85-95.

3. Жукова О. В. Трансфертне ціноутворення: український варіант / О. В. Жукова, В. І. Дубницький, В. О. Вареня. - К. : Ліра-К, 2014. - 184c.

4. Мельник М.I., Лещух І.В. Податковий контроль в Україні: проблеми та пріоритети підвищення ефективності : монографія / М.І. Мельник, І.В. Лещух. - Львів : ДУ «Інститут регіональних досліджень ім. M.I. Долішнього НАН України», 2015. - 330 с.

5. Рогова Н. В. Облікове забезпечення контролю трансфертного ціноутворення / Н. В. Рогова // Економіка: реалії часу. - 2014. - № 5. - С. 204-207.

6. Засадний Б. Формування облікової політики підприємства щодо пов’язаних сторін / Б. Засадний // Вісник Київського національного університету імені Тараса Шевченка. Економіка. - 2015. - Вип. 10. - С. $24-30$.

7. Литвиненко Н.О. Аналітичний облік внутрішніх розрахунків / Н.О. Литвиненко // Науковий вісник НЛТУ України. - 2013. - Вип. 23.2. - С. 277- 284.

8. Костюченко В.М. Методологія й організація обліку і аналізу діяльності юридичної особи та їі дочірніх підприємств як єдиної економічної одиниці: дис. д-ра екон. наук: спец. 08.00.09 - "Загальна теорія бухгалтерського обліку" / Костюченко Валентина Миколаївна; Київський НУ ім. В. Гетьмана. - К. : Вид-во "Наука", 2008. - 651 с.

9. Гойло Н.В. Трансфертне ціноутворення при здійсненні внутрішньогрупових операцій: поняття та вплив на показники фінансової звітності / Н.В. Гойло // Економіка: реалії часу. Науковий журнал. - 2016. - № 3 (25). C. $150-160$

10. Мішин М. Пов'язаність осіб для цілей трансфертного ціноутворення: правові засади та математичні розрахунки./ Вісник Міністерства доходів і зборів України. -2014. - №1. - с.35-38.

11. Сопко В.В. Організація бухгалтерського обліку, економічного контролю та аналізу : підручник /В.В.Сопко, В.П.Завгородній// - [Електронний ресурс]. - Режим доступу: http://studentbooks.com.ua/ content/view/130/35/1/0/

12. Податковий кодекс України від 02.12.2010 p. № 2755-VI [Електронний ресурс]. - Режим доступу: http://zakon2.rada.gov.ua/laws/show/2755-17

13. Настанови Організації економічного співробітництва та розвитку щодо трансфертного ціноутворення для транснаціональних компаній та податкових служб від 22.07.2010 р. [Електронний ресурс]. - Режим доступу: http://minrd.gov.ua/data/material/000/021/80820/0.pdf.

14. Закон України «Про бухгалтерський облік та фінансову звітність в Україні» від 16.07.1999 р. № 996 [Електронний ресурс]. - Режим доступу : http://zakon3.rada.gov.ua/laws/show/996-14

15. План рахунків бухгалтерського обліку активів, капіталу, зобов'язань і господарських операцій підприємств і організацій: Наказ Міністерства фінансів України від 30.11.1999 р. № 291. [Електронний ресурс]. — Режим доступу: http://zakon.rada.gov.ua/go/z0893-99

16. Звіт про контрольовані операції: Наказ Міністерства фінансів України 18.10.2016 р. № 8 [Електронний pecypc]. - Режим доступу: http://zakon0.rada.gov.ua/ laws/show/z0187-16/print1467358644432696.

\section{REFERENCES}

1. Ofitsiinyi sait Derzhavnoji fiskaljnoji sluzhby Ukrajiny [The official website of the State Fiscal Service of Ukraine ]. http://sfs.gov.ua. Retrieved from http://sfs.gov.ua [in Ukrainian].

2. Aleksieieva A., \& T. Ihnatenko (2014) Transfertne tsinoutvorennia yak mekhanizm podatkovoho kontroliu [Transfer pricing as a mechanism for tax control]. Visnyk Kyivskoho natsionalnoho torhovelno-ekonomichnoho universytetu, ( 3), 85-95 [in Ukrainian].

3. Zhukova O. V., \& . Dubnytskyi, V. O., \& V. O. Varenia (2014) Transfertne tsinoutvorennia: ukrainskyi variant [Transfer pricing: Ukrainian version]. Lira [in Ukrainian].

4. Melnyk M.I., \& Leshchukh I.V. (2015) Podatkovyi kontrol v Ukraini: problemy ta priorytety pidvyshchennia efektyvnosti [Tax Control in Ukraine: Problems and Priorities for Efficiency] : monohrafiia Lviv : DU «Instytut rehionalnykh doslidzhen im. M.I. Dolishnoho NAN Ukrainy» [in Ukrainian].

5. Rohova N. V. (2014) Oblikove zabezpechennia kontroliu transfertnoho tsinoutvorennia [Accounting control of transfer pricing control]. Ekonomika: realii chasu, (5), 204-207 [in Ukrainian].

6. Zasadnyj B. (2015) Formuvannja oblikovoji polityky pidpryjemstva shhodo pov'jazanykh storin [Formation of accounting policies of the enterprise related parties].Visnyk Kyjivsjkogho nacionaljnogho universytetu imeni Tarasa Shevchenka. Ekonomika, (10), 24-30 [in Ukrainian].

7. Lytvynenko N.O. (2013) Analitychnyj oblik vnutrishnikh rozrakhunkiv [Analytical accounting of internal settlements]. Naukovyj visnyk NLTU Ukrajiny, (23.2), 277-284 [in Ukrainian].

8. Kostjuchenko V.M. (2008) Metodologhija j orghanizacija obliku i analizu dijaljnosti jurydychnoji osoby ta jiji dochirnikh pidpryjemstv jak jedynoji ekonomichnoji odynyci [Methodology and organization of accounting and analysis of the legal entity and its subsidiaries as a single economic unit] Doctor thesis. Kyiv. Kyivskyi natsionalnyi universytet im. V. Hetmana [in Ukrainian]. 
9. Hoilo N.V. (2016) Transfertne tsinoutvorennia pry zdiisnenni vnutrishnohrupovykh operatsii: poniattia ta vplyv na pokaznyky finansovoi zvitnosti [Transfer pricing in carrying out intra-group transactions: the concept and impact on financial statements]. Ekonomika: realii chasu. Naukovyi zhurnal, (3(25)), 150-160 [in Ukrainian].

10. Mishyn M. (2014) Poviazanist osib dlia tsilei transfertnoho tsinoutvorennia: pravovi zasady ta matematychni rozrakhunky [Connectivity persons for the purposes of transfer pricing, legal principles and mathematical calculations].Visnyk Ministerstva dokhodiv i zboriv Ukrainy, (1), 35-38 [in Ukrainian].

11. Sopko V.V. Orhanizatsiia bukhhalterskoho obliku, ekonomichnoho kontroliu ta analizu [Organization of accounting, economic control and analysis] Retrieved from: http://studentbooks.com.ua/content/view/ 130/35/1/0/ [in Ukrainian].

12. Podatkovyy kodeks Ukrayiny № 2755-VI vid 02.12.2010 r. Zatverdzhenyy Verkhovnoyu radoyu Ukrayiny [Tax Code of Ukraine № 2755-VI of 02.12.2010. Approved by the Verkhovna Rada of Ukraine] Retrieved from: http://zakon4.rada.gov.ua/laws/show/2755-17 [in Ukrainian].

13. Nastanovy Orhanizatsiyi ekonomichnoho spivrobitnytstva ta rozvytku shchodo transfertnoho tsinoutvorennya dlya transnatsionalnykh kompaniy ta podatkovykh sluzhb vid 22.07.2010 r. [Guidance Organization for Economic Cooperation and Development on transfer pricing for multinational enterprises and tax authorities on 22.07.2010] Retrieved from: http://minrd.gov.ua/data/material/000/021/80820/0.pdf [in Ukrainian].

14. Zakon Ukrainy «Pro bukhhalterskyi oblik ta finansovu zvitnist v Ukraini» 16.07.1999 r. № 996-XIV [Law of Ukraine «On Accounting and Financial Reporting in Ukraine» from 16.07.1999, № 996-XIV] Retrieved from http://zakon3.rada.gov.ua/laws/show/996-14 [in Ukrainian].

15. Plan rakhunkiv bukhhalterskoho obliku aktyviv, kapitalu, zoboviazan i hospodarskykh operatsii pidpryiemstv i orhanizatsii: Nakaz Ministerstva finansiv Ukrainy 30.11.1999 p. № 291 [Plan of accounting of assets, capital, liabilities and business operations of enterprises and organizations] Retrieved from: http://zakon.rada.gov.ua/go/z0893-99 [in Ukrainian].

16.Zvit pro kontrolovani operatsiyi zatverdzhenyy: Nakaz Ministerstva finansiv Ukrayiny 18.10.2016 r. № 8 [Report controlled operations approved by the Ministry of Finance of Ukraine 18.10.2016 №8] Retrieved from: http://zakon0.rada.gov.ua/laws/show/z018716/ print1467358644432696 [in Ukrainian]. 